\title{
Kriteria Guru Pak Dalam Membentuk Jati Diri Remaja Usia 12-15 Tahun
}

\author{
Ester Lina Situmorang ${ }^{1 *}$ Rikardo Dayanto Butar-Butar, ${ }^{2}$ Mega Mustika Zega ${ }^{3}$ \\ Prodi Studi PAK, STT Real Batam \\ Prodi Studi PAK, STT Real Batam \\ Prodi Studi PAK, STT Real Batam \\ estherlina1204@yahoo.com
}

\begin{abstract}
This paper starts from the problems that are often seen in the lives of adolescents, in their growth period who are looking for identity tend not to recognize their true identity. Formation of identity is often used as a trigger for disputes for students due to errors in placement. This can be seen from the behavior of students who are arbitrary, disrespectful, always looking for a fuss, no longer even respect their teacher, and no longer reflect God-fearing behavior and its relation to fellow human beings. The author also sees that students in junior high school have shown rebellion like students against their teacher, likes to annoy their friends while learning and saying dirty words The period is a period where the transition from childhood to half-adult trying to find who he is, or called the search for identity himself. This is caused by adolescents being less careful in socializing, and tends to assume their actions are right. Therefore the ability needed is the teacher who can shape the child's identity. Most teachers focus more on forming their intelligence and often neglect the formation of their positive identity. In connection with that, the writing of this journal the writer formulated the problem as follows: first, What are the positive identities that need to be formed in junior high school students. Second, What are the criteria for Christian religious education teachers as spiritual guides. After the research data is collected, the writer processes and analyzes finding out how Christian education learning for the formation of a positive identity among junior high school students. To find answers, the authors adjust the data with the literature review data discussed in chapter two, with a simple analysis of using descriptive methods or the authors try to find things that are important in relation to the formation of a positive identity for junior high school students. After all of them are analyzed, the writer can finally conclude that the teacher of Christian religious education as a spiritual guide in the school has a great influence in the formation of a positive identity among junior high school students. A PAK teacher as a spiritual guide in a school has a major contribution to the effort to establish a positive identity among junior high students.
\end{abstract}

Keywords: Criteria, PAK Teachers, Identity, Early Adolescents

\begin{abstract}
Abstrak
Tulisan ini bertitik-tolak dari masalah-masalah yang sering terlihat dalam kehidupan anak remaja, dalam masa pertumbuhan yang mencari jati diri cenderung tidak mengenal jati dirinya yang sebenarnya. Pembentukan jati diri sering dijadikan pemicu perselisihan bagi peserta didik akibat kesalahan dalam penempatannya. Hal ini bisa dilihat dari perilaku peserta didik yang sesuka-hati, tidak sopan, selalu mencari keributan, bahkan tidak lagi menghargai gurunya, serta tidak lagi mencerminkan perilaku yang takut akan Tuhan dan kaitannya terhadap sesama manusia. Penulis juga melihat bahwa peserta didik di kalangan SMP telah menunjukkan sikap membrontak seperti peserta didik melawan gurunya, suka mengganggu temannya sewaktu belajar dan mengucapkan kata-kata kotor Masa merupakan masa dimana peralihan kanak-kanak menuju setengah dewasa
\end{abstract}


berusaha mencari siapa dirinya, atau disebut pencarian jati dirinya.Ini diakibatkan karena remaja kurang berhati-hati dalam bergaul, dan cenderung menganggap tindakannya adalah benar. Maka dari itu kemampuan yang diperlukan adalah guru yang dapat membentuk jati diri anak tersebut. Kebanyakan guru-guru lebih berfokus pada pembentukan intelegensinya dan sering mengabaikan pembentukan jati dirinya yang positif. Sehubungan dengan itu maka penulisan jurnal ini penulis merumuskan permasalahan sebagai berikut: pertama, Apa saja jati diri positif yang perlu dibentuk dalam diri siswa SMP. Kedua, Apa saja kriteria guru pendidikan agama kristen sebagai pembimbing rohani. Setelah data-data penelitian terkumpul, penulis mengolah dan menganalisa mencari tahu bagaimana pembelajaran pendidikan kristen bagi pembentukan jati diri positif dikalangan siswa SMP. Untuk menemukan jawaban, penulis menyesuaikan data dengan data literature review yang di bahas di bab dua, dengan analisa sederhana yaitu menggunakan metode deskriptif atau penulis mencoba menemukan hal-hal yang penting dalam hubungannya dengan pembentukan jati diri yang positif bagi siswa SMP. Setelah semuannya di analisa maka akhirnya penulis bisa menyimpulkan bahwa guru pendidikan agama kristen sebagai pembimbing rohani di sekolah mempunyai pengaruh besar dalam pembentukan jati diri yang positif di kalangan siswa SMP. Seorang guru PAK sebagai pembimbing rohani di sekolah mempunyai kontribusi yang besar bagi usaha pembentukan jati diri yang positif di kalangan siswa SMP.

Kata - kata Kunci: Kriteria,Guru PAK, Jati Diri, Remaja Awal

\section{PENDAHULUAN}

Peralihan kanak-kanak menuju remaja awal berusaha mencari siapa dirinya, anakanak usia remaja awal khususnya yang sudah mulai belajar di tingkat SMP adalah masa pembentukan identitas atau Jati diri dimana masa peralihan dari masa kanak-kanak menuju dewasa, dimana peralihan dari masa kanak kanak menuju dewasa masa ini merupakan masa yang labil. ${ }^{1}$ Permasalahan remaja mulai dari masalah pacar, masalah sekolah, masalah pergaulan, masalah penampilan dan lain sebagainya. Namun, permasalahan tersebut sebenarnya adalah proses pencarian jati diri yang bakal menjadi sebuah dari kedewasaan. Remaja pada jaman sekarang ini seringkali tidak mengenal jati dirinya yang sebenarnya. Ini diakibatkan karena peserta remaja kurang berhati-hati dalam bergaul, dan cenderung menganggap tindakannya adalah benar. Dan juga diakibatkan atas perbedaan sifat, perilaku, watak dari perserta didik. Contohnya : Suka Memberontak: Dalam masa pertumbuhan yang mencari jati diri remaja cenderung menginginkan agar supaya apa yang di inginkan dapat tercapai atau terpenuhi. Dampak yang kurang baik bila keinginannya tidak terpenuhi atau tidak sependapat dengan apa yang kita ingin mereka lakukan maka dia akan memberontak. Hasilnya tumbuh pembangkangan terhadap aturan dengan alasan mencari jati diri. Remaja beranggapan bahwa jati diri mengatakan "tidak" pada semua aturan itu.

Saat ini banyak sekali para remaja yang kesulitan mengetahui jati dirinya, oleh karena itu sikap dalam mencari jati diri jangan dijadikan sebagai pemicu perselisihan dalam mengembangkan potensi-potensi yang ada dalam diri peserta didik. Pembentukan jati diri

\footnotetext{
${ }^{1}$ S.H Arniwati, dan R.Budyarto, Dampak Teknologi Terhadap Kehidupan Rohani Anak Dan Remaja (Surabaya: Gandum Mas, 2012). Hal,11.
} 
sering dijadikan pemicu perselisihan bagi peserta didik akibat kesalahan dalam penempatannya. Hal ini bisa dilihat dari perilaku peserta didik yang sesuka-hati, tidak sopan, selalu mencari keributan, bahkan tidak lagi menghargai gurunya, serta tidak lagi mencerminkan perilaku yang takut akan Tuhan dan kaitannya terhadap sesama manusia. Penulis juga melihat bahwa peserta didik di kalangan SMP telah menunjukkan sikap membrontak seperti peserta didik melawan gurunya, suka mengganggu temannya sewaktu belajar dan mengucapkan kata-kata kotor.

Sebagai guru PAK yang berperan sebagai guru Pembimbing Rohani atau "imam" berarti mewakili Tuhan kepada murid-murid, menjadi teladan bagi anak didik, membawa dalam doa kepada Tuhan, dan berusaha mencegah dan memulihkan situasi yang rusak. Guru sebagai Pembimbing Rohani harus mampu menunjukkan sosok kepribadiannya yang benar-benar memiliki perbedaan dengan guru-guru bidang studi lainnya. Namun hal ini masih sering dijumpai bahwa guru PAK mengajar tidak berdasarkan metode/gaya mengajar yang dimiliki Tuhan Yesus. Tidak mempergunakan bagaimana gaya ataupun cara Tuhan Yesus dalam mengajar murid-muridNya, dan cara Tuhan Yesus dalam memberikan motivasi kepada muridNya. Sekarang ini banyak guru Pendidikan Agama Kristen mengajar hanya sebatas menyampaikan materi pembelajaran. Kebanyakan guru-guru lebih berfokus pada pembentukan integensinya dan sering mengabaikan pembentukan jati dirinya yang positif. Maka dari itu kemampuan yang diperlukan adalah guru yang dapat membentuk jati diri anak tersebut. Oleh karena itu, motivasi guru Pendidikan Agama Kristen dalam kegiatan belajar dapat memengaruhi karakter peserta didik atas motivasimotivasi yang diberikan oleh guru Pendidikan Agama Kristen. Seperti yang disampaikan oleh Boiliu Pendidikan karakter sangat penting untuk mengubah siswa dari generasi pemberontak pada pengikut Kristus. ${ }^{2}$

\section{METODE}

Metode penulisan yang digunakan adalah Metode kualitatif deskriptif,bersifat literature terhadap beberapa sumber pustaka yang terkait dengan topik bahasan mengenai Kriteria guru PAK dalam membentuk jati diri remaja yang mengumpulkan data - data yang bersumber dari buku - buku ,materi materi dengan wawasan karya ilmiah secara umum.

\section{HASIL DAN PEMBAHASAN}

\section{Membentuk Jati Diri Positif Remaja}

Jati diri adalah sekumpulan karakter intelektual, emosional maupun sosial yang dimiliki oleh seseorang, termasuk di dalamnya adalah perasaan dan persepsi. ${ }^{3}$ Jati diri juga

\footnotetext{
${ }^{2}$ Jurnal Teologi et al., "Mengajarkan Pendidikan Karakter Melalui Matius 5 : 6-12” 1, no. May (2020): 612.

${ }^{3}$ MUSTHOFA ABU SA'ID, Buku Pintar Mendidik Remaja, ed. Ahmad Asrof Fitri (Yogyakarta: Semesta Hikmah, 2017). Hal.111
} 
menggambarkan secara esensial tentang seseorang seperti karakter, sifat, watak, kepribadian ,moralnya, ekspresi batin mengenai tempat dan peran, guna menemukan arti kehidupan yang hakiki, sebagai tuntutan hidup dalam menemukan kebahagiaan sejati hidup.

Masa remaja dapat dilihat pada fisik yang berubah cepat, berat badan bertambah dan tinggi badan, bentuk tubuh, dan perkembangan karakteristik Perubahan fisik akan berakibat langsung pada sikap dan perilaku dan mempunyai akibat jangka panjang sehingga periode ini merupakan periode yang menentukan bagi seorang remaja atas masa depannya. Pada perkembangan ini, pencapaian kemandirian dan proses pencarian jati diri menjadi sangat menonjol. Mereka akan semakin banyak menghabiskan waktu di luar rumah. Dampak pergaulan di kalangan remaja ini sangat besar pengaruhnya, karena akan banyak membentukan karakter dan perilaku dari jati diri remaja. Dari pergaulan itu, mereka akan belajar semua hal dan mencontoh semua tindakan dari teman-teman sebayanya. Kecenderungannya, mereka akan terima semua itu tanpa bisa membedakan mana yang baik dan buruk. Sedangkan secara Psikologis, anak-anak usia remaja sering mengalami keresahan, kebimbangan, bahkan tekanan. Begitu juga Secara Sosial,Pada usia ini, seorang anak senang berdebat dan mengkritik. Secara Intelektual pada usia remaja secara mental anak telah dapat berfikir logis tentang berbagai gagasan yang abstrak.Pada tahap ini remaja mempunyai pola pikir sendiridalam usaha memecahkan masalah-masalah.

Secara Rohani Frustasi dan keragu-raguan yang dialami oleh anak-anak awal remaja di bidang lain dapat terbawa ke bidang rohani juga. Remaja yang tidak senang pada diri sendiri dapat menemukan kesulitan untuk percaya bahwa Allah yang menciptakan mereka itu penuh kasih dan baik hati. Mereka membutuhkan pertolongan dan pengertian pada masa kritis ini. Orang tua dan guru harus menerima mereka sebagaimana adanya dan berusaha membangun perhubungan dengan mereka di mana kepercayaan dapat berkembang. Ketika berhubungan dengan mereka baik di dalam maupun di luar kelas, guru dapat menolong mereka melihat bahwa mereka tidak seharusnya berjalan sendiri dalam kesulitan mereka. Bila Yesus mengendalikan hidup mereka, mereka dapat memiliki kuasaNya untuk menolong mereka hidup berkemenangan dan kehadiranNya untuk mendorong, menghibur, dan menyokong mereka dan dapat menolong mereka menghadapi persoalan-persoalan hidup ketika mengajar mereka menyesuaikan hidup menurut prinsip Alkitab.

Bagi remaja Kristen pengenalan diri tidaklah hanya berdasarkan pandangan diri sendiri namun berdasarkan pandangan Tuhan ,seharusnya mampu menilai dirinya berharga dan mulia dihadapan Tuhan dan manusia (Yes.43:4), (Kej. 1:26) Remaja yang memiliki penilaian positif, menjadikan pikiran yang tinggi tentang diri sendiri sebagaimana Allah melihat diri. Oleh karena itu pembentukan jati diri suatu langkah untuk mempersiapkan langkah lebih baik, dan menuju yang lebih baik. Pembentukan jati diri bagi remaja sangatlah penting karena sebuah modal terbesar bagi kemajuan dirinya. 


\section{Mampu Menguasai Diri}

Penguasaan diri adalah kemampuan untuk mendeteksi dan mengatasi tekanantekanan negatif yang muncul dalam kehidupan. Penguasaan diri berarti berani dan mampu berkata tidak terhadap segala sesuatu yang merugikan diri-sendiri dan orang lain, baik secara fisik, emosi, moral, maupun spiritual . Penguasaan diri akan membentuk kita menjadi pribadi yang lebih dewasa. Dengan penguasaan diri, kita tidak akan mudah terbawa arus dosa duniawi. Dengan memiliki karakter ini, kita akan semakin serupa dengan juruselamat kita, Yesus Kristus. Unsur yang dikendalikan adalah segenap aktivitas kepribadian yang menyangkut akal budi, emosi atau perasaan dan kehendak. Remaja yang sudah belajar dan menerapkan penguasaan diri akan menjadi remaja yang dapat mencapai tugas perkembangan.

Perkembangan masa remaja adalah memperluas hubungan pribadi, berkomunikasi secara lebih dewasa, memperoleh peranan sosial di keluarga maupun masyarakat, menerima kondisi fisiknya, memperoleh kebebasan emosional dari sekitarnya, mencapai kepastian akan kebebasan dan kemampuan berdiri sendiri, memilih dan mempersiapkan lapangan pekerjaan, membentuk sistem nilai moral dan falsafah hidup. Mampu menguasai dirinya adalah kemampuan untuk memimpin, mengatur, dan menata diri sendiri secara bijaksana .Jika remaja dan kelompok pertemanannya dapat membangun konsep diri yang positif akan menjadikan kekuatan utama dalam diri remaja tersebut. Sehingga dalam penerapan kehidupan di masa remaja, perilaku kontrol diri dan tanggung jawab serta perencanaan kehidupan selanjutnya sangat dibutuhkan bagi remaja yang sedang mencari jati di

\section{Berani Bertanggung Jawab}

Menjalani masa remaja tidak selalu mudah. Pada dasarnya, remaja yang bertanggung jawab adalah remaja yang mengenal diri sendiri dan mematuhi aturan : 1 . bertanggung jawab dalam belajar dan bekerja yaitu belajar dengan tekun, 2. Menjaga kesehatan dan kebersihan misalnya mengonsumsi makanan sehat, membiasakan berolahraga, menghindari obat terlarang. 3. Menjaga sikap seperti membiasakan hidup jujur, tidak membuat sakit hati temannya, menghormati yang lebih dewasa darinya. Melakukan hal-hal positif dan berkumpul dengan orang-orang positif membuat Anda lebih bahagia dan lebih bertanggung jawab.

\section{Kriteria Guru Pak Membentuk Jati Diri Remaja}

Guru PAK adalah seorang yang memberikan ilmu pengetahuan tentang agama Kristen yang berdasarkan Alkitab, berpusat pada Yesus Kristus, dan bergantung pada Roh Kudus kepada peserta didik dalam kegiatan belajar mengajar, agar para peserta didik dapat mengenal Allah dan kasih-Nya yang dilakukan dalam bentuk pengajaran, bimbingan, pelatihan, pembinaan, tuntunan baik di dalam kelas maupun di luar kelas serta bertanggung 
jawab atas perkembangan rohani peserta didik. Guru pendidikan agama kristen adalah hamba-hamba Tuhan yang mengajar dengan tujuan tertinggi yakni mempersiapkan generasi yang takut kepada Tuhan. ${ }^{4}$ Guru Pendidikan Agama Kristen juga merupakan satu pendukung yang penting dalam mewujudkan proses belajar mengajar dalam mengerjakan Firman Tuhan dan pengarah bagi setiap murid untuk belajar dengan baik terlebih khusus di dalam pengenalan akan Tuhan.

Guru PAK sebagai pembimbing rohani merupakan guru sebagai pendengar kegelisahan dan persoalan muridnya, lalu bersama-sama mencari upaya mengatasinya dalam terang firman Tuhan serta pertolongan Roh Kudus. ${ }^{5}$ Guru pendidikan agama Kristen sebagai pembimbing rohani adalah guru PAK yang mampu dan selalu bersedia mendekati murid-muridnya dengan memperhatikan kepribadian masing-masing anak didik dan berfungsi untuk membantu para siswa mengenal Allah di dalam Yesus Kristus, memiliki pikiran Kristus, membantu mempersiapkan siswa menjadi umat yang layak di hadapan Tuhan dan hidup sesuai firmanNya. Guru pembimbing adalah Guru yang dapat menuntun, mengasuh mendampingi, mendorong dan membantu perkembangan rohani siswa.

\section{Memiliki Keterpanggilan sebagai Pembimbing Rohani}

Perlu kita sadari bahwa kita adalah orang yang berdosa, sementara Tuhan yang empunya ladang pelayanan adalah kudus. Kalau kita bisa dipanggil untuk melayani itu adalah anugerah Tuhan. Sebagai seorang guru terutama guru pendidikan agama Kristen tidak boleh seenaknya memandang dan melaksanakan pekerjaannya sebagai suatu hal yang biasa-biasa saja, hanya sekedar untuk mendapat imbalan darinya, tetapi harus dipahami bahwa profesinya sebagai guru adalah panggilan yang berasal dari Allah, karena itu harus dipertanggung jawabkan juga kepada Allah. Guru yang benar-benar memahami arti panggilannya tidak akan merasa pekerjannya sebagai sebuah beban, dan melaksanakannya dengan terpaksa sekalipun banyak masalah yang dihadapi. Guru akan merasa senang jika melihat anak didiknya bertumbuh, sangat berbahagia jika melihat anak didiknya berhasil kelak, dan akan merasa bangga bahkan meneteskan air mata bila melihat mantan muridnya menjadi orang berguna.

Pada dasarnya guru Kristen, memiliki peran yang tidak hanya untuk mengajar tetapi guru juga merupakan instrumen Allah. Artinya bahwa guru dalam melaksanakan pekerjaannya harus dengan kerendahan hati, karena otoritas mereka, pesan, posisi, dan panggilan untuk melayani semua datang dari Allah. Guru berkewajiban memberikan bantuan kepada murid agar mereka mampu menemukan masalah sendiri, memecahkan masalah nya sendiri, mengenal diri sendiri dan menyesuaikan diri dengan lingkungan nya. ${ }^{6}$ John M. Nainggolan tanggung jawab guru PAK adalah "guru memberi

\footnotetext{
${ }^{4}$ Manahan Uji Simanjuntak.,MA.,M.Pd.K, Kompetensi Guru PAK (Batam, 2014). Hal, 37.

${ }^{5}$ Ph.D B.S. Sidjabat, Mengajar Secara Profesional (Bandung -Jawa Barat: Kalam Hidup, 2017).Hal,123.

${ }^{6}$ Oemar Hamalik, Proses Belajar Mengajar (Jakarta: PT Bumi Aksara, 2001).Hal 124
} 
tenaga, waktu tanpa pamrih kepada murid-murid-Nya setia hari. Ini merupakan hal yang biasa yang dikerjakan oleh guru senantiasa dalam hidupnya". ${ }^{7}$ Melalui panggilan keguruan yang Allah tetapkan untuk guru Pendidikan Agama Kristen, diharapkan salah satu tugas Pendidikan Agama Kristen yaitu membawa anak agar percaya dan menerima Yesus Kristus sebagai juru selamat pribadi, dan tugas ini dikenal dengan istilah penginjilan.

\section{Memiliki Keteladan Hidup}

Keteladanan merupakan hal yang paling utama dalam membentuk dan mendidik karakter anak. Thomas Lickona mengatakan "meneladankan sendiri proses itu, sehingga kaum muda mempunyai orang dewasa dalam kehidupan mereka yang terlihat bertekad menggapai cita-cita yang tinggi dan berjuang mengaktualisasikan secara lebih penuh". ${ }^{8}$ Artinya, tidak ada pembentukan karakter yang jadi tanpa ada teladan.Tuhan Yesus Kristus adalah teladan hidup kita, tetapi orang tua juga sebagai teladan bagi anak.Keteladanan hidup guru dan orang tua dalam membentuk karakter atau kepribadian anak sangatlah penting. B. S. Sidjabat mengatakan "sebagai guru, kepribadian yang mantap dan stabil, dewasa, arif, berwibawa, berbudi luhur serta layak dijadikan teladan dapat memberikan pelajaran bagi siswa". ${ }^{9}$

Guru pendidikan agama kristen sebagai pembimbing rohani tidak dapat dipisahkan dari sikap keteladannya sebagai bagi anak remaja dan bagi semua orang, baik dalam hal perkataan, tingkah laku, maupun dalam kasih, kesetiaan, dan kesucian. Berkaitan dengan hal di atas, seorang Guru sebagai pembibing rohani harus memiliki perkataan yang jujur, berpegang kepada Firman Allah, dan harus dikendalikan oleh Roh Kudus dan Firman Allah. Konsep Perjanjian Baru mengenai kepemimpinan, menuntut para penatua agar memandang diri sebagai hamba bagi yang lain, "hendaklah menjadi teladan (I Petrus $5: 3)^{\prime \prime}{ }^{10}$

Peranan seorang Guru sebagi pembimbing rohani dituntut tampil sebagai teladan bagi siswa seperti Rasul Petrus menyampaikan nasihatnya kepada para penatua "janganlah kamu berbuat seolah-olah kamu mau memerintah atas mereka yang dipercayakan kepadamu, tetapi hendaklah kamu menjadi teladan bagi kawanan domba itu." Tetapi biarlah orang itu menyadari bahwa kedudukannya sebagai seorang pemimpin meliputi kewajiban untuk lebih matang, lebih rohani, lebih setia, lebih bertekun di dalam doa, dan lebih saleh daripada anggotanya.

Guru pendidikan agama kristen sebagai pembimbing rohani harus memperhatikan bahwa guru menjadi teladan yang baik bagi kawanan dombanya dalam semua hal". ${ }^{11}$

\footnotetext{
${ }^{7}$ John M. Nainggolan, Guru Agama Kristen (Bandung: Jurnal Info Media, 2006). Hal,30.

${ }^{8}$ Thomas Lickona, Pendidikan Karakter (Bantul: Kreasi Wacana, 2012). Hal, 27.

${ }^{9}$ B.S. Sidjabat, Mengajar Secara Profesional. Hal,72.

${ }^{10}$ Ronald W.Liegh, Melayani Dengan Efektif (Jakarta: BPK Gunung Mulia, n.d.). Hal,222.

${ }^{11}$ Ralp M. Riggs, Gembala Sidang Yang Berhasil (Malang: Yayasan penerbit Gandum Mas, 1996). Hal,67.
} 
Sejalan dengan apa yang dimaksudkan Myron Rush, dalam bukunya menyatakan bahwa, salah satu peranan utama dari seorang pemimpin yang berhasil adalah menunjukkan teladan yang baik, kemudian melatih orang lain. ${ }^{12}$ Menurut Kamus Besar Bahasa Indonesia, kata "teladan" adalah patut ditiru, baik untuk dicontohi. ${ }^{13}$ Dari uraian di atas jelas bahwa tanggung jawab dan peranan seorang gembala sebagai pemimpin dituntut adanya sikap teladan dalam seluruh aspek kehidupannya. J.M Price, dalam Buku Yesus Guru Agung, mengatakan bahwa : Yang menjadi syarat terpenting bagi guru ialah kepribadiannya. Sebuah teladan lebih berharga dari pada seratus kata nasehat. Perbuatan lebih berpengaruh daripada perkataan. ${ }^{14}$

\section{Memiliki Keterampilan Dan Berkualitas Dalam Mengajar}

Keterampilan yang dimaksud adalah kemampuan guru PAK sebagai pembimbing rohani untuk mengajarkan siswa dalam membentuk kepribadian mereka sama seperti Kristus melalui keterampilan ,motivasi dan bimbingan belajar. Bimbingan kepada murid agar mereka mampu menghadapi kenyataan dan memiliki stamina emosional yang baik, perlu dibimbing kearah terciptanya hubungan pribadi yang baik dengan temanya dimana perbuatan dan perkataan guru dapat menjadi contoh yang hidup ${ }^{15}$ Guru juga dipandang sebagi orang yang paling berpengetahuan, dan harus terus mengembangkan pengetahuan terus menerus, dimana pengetahuan dan teknologi berkembang dengan pesat, guru harus mengikuti dan menyesuaikan diri dengan perkembangan tersebut, karena Guru merupakan unsur terpenting dalam kegiatan belajar mengajar, sebagai seorang pengajar kualitas pengajaran sangat dibutuhkan di dalam suatu lembaga pendidikan. Untuk itu guru PAK perlu terus belajar meningkatkan dirinya, serta menguasai Ilmu pengetahuan Karena Guru dipandang sebagai orang yang paling mengetahui, karena guru adalah yang paling pandai dalam menyiapkan tugas tugas, memberikan latihan latihan dan penilaian menjadi pribadi yang handal dihadapan Tuhan serta dipakai untuk membina iman siswa supaya lebih mengenal dan beriman kepada Allah.

Kerangka pemikiran atau pandangan dunia tentang pendidikan karakter menurut Yesus didasarkan pada perubahan batin dalam diri seseorang. Ini adalah motif atau dasar dari setiap manusia untuk melakukan segala sesuatu atau tindakan serta karakter. Ini dimulai dengan perubahan mental atau batin seseorang atau apa yang disebut revolusi batin manusia. Hal ini sangat penting karena merupakan perubahan mendasar dalam diri manusia dan membuatnya bermartabat dan manusiawi. ${ }^{16}$

\section{KESIMPULAN}

\footnotetext{
${ }^{12}$ Myron Rush, Pemimpin Baru (Jakarta: Yayasan Pekabaran Injil /Immanuel, 1991). Hal,23.

13 "Kamus Besar Bahasa Indonesia, S.V."

14 Timotius-Sukarman, "Profesionalitas-Guru-Pak."

15 (Oemar Hamalik, 2001) Hal. 129

16 Teologi et al., "Mengajarkan Pendidikan Karakter Melalui Matius 5 : 6-12."
} 
Guru PAK merupakan satu pendukung yang penting dalam mewujudkan pembentukan jati diri anak remaja dalam mengerjakan Firman Tuhan, sebagai pengarah bagi setiap murid untuk belajar dengan baik, mampu dan selalu bersedia mendekati muridmuridnya dengan memperhatikan kepribadian masing-masing anak didik dan berfungsi untuk membantu para siswa mengenal Allah di dalam Yesus Kristus, memiliki pikiran Kristus, serta membantu mempersiapkan siswa menjadi umat yang layak di hadapan Tuhan dan hidup sesuai firmanNya.

Oleh karena itu, Guru Pendidikan Agama Kristen sebagai pembimbing rohani membawa anak kedalam perubahan diri ke arah positif yaitu sesuai dengan Firman Tuhan dan siswa memiliki jati diri yang baik seperti Tuhan Yesus Kristus. Guru PAK harus memiliki Kriteria yang memiliki Keterpanggilan sebagai Pembimbing Rohani yang merupakan panggilan Allah yang harus dikerjakan dengan sungguh-sungguh, Memiliki Keteladan Hidup, Memiliki Keterampilan dan berkualitas dalam mengajar dalam membina, membimbing para muridnya menjadi murid Yesus yang sejati, Oleh karena itu Guru PAK harus mempersiapkan dirinya sebaik mungkin dan menjadi teladan anak didik.

\section{KEPUSTAKAAN}

Andry ochran. "Penguasaan Diri."

Arniwati, dan R.Budyarto, S.H. Dampak Teknologi Terhadap Kehidupan Rohani Anak

Dan Remaja. Surabaya: Gandum Mas, 2012.

B.S. Sidjabat, Ph.D. Mengajar Secara Profesional. Bandung -Jawa Barat: Kalam Hidup, 2017.

Hendra Rey. Menata Hati Serupa Kristus. Bandung: Pt.Visi Anugrah Indonesia, 2014. John M. Nainggolan. Guru Agama Kristen. Bandung: Jurnal Info Media, 2006. Manahan Uji Simanjuntak.,MA.,M.Pd.K. Kompetensi Guru PAK. Batam, 2014. Myron Rush. Pemimpin Baru. Jakarta: Yayasan Pekabaran Injil /Immanuel, 1991. Prof.Dr. Oemar Hamalik. Proses Belajar Mengajar. Jakarta: PT Bumi Aksara, 2001.

Ralp M. Riggs. Gembala Sidang Yang Berhasil. Malang: Yayasan penerbit Gandum Mas, 1996.

Ronald W.Liegh. Melayani Dengan Efektif. Jakarta: BPK Gunung Mulia, n.d.

Syaifullah. Tips Bisa Percaya Diri, n.d.

Teologi, Jurnal, Agama Kristen, Ibrahim Boiliu, Aeron Frior Sihombing, Christina M

Samosir, and Fredy Simanjuntak. "Mengajarkan Pendidikan Karakter Melalui Matius 5 : 6-12" 1, no. May (2020): 6-12.

Thomas Lickona. Pendidikan Karakter. Bantul: Kreasi Wacana, 2012.

Timotius-Sukarman. "Profesionalitas-Guru-Pak."

"Apa Itu Jati Diri."

"Kamus Besar Bahasa Indonesia, S.V." 